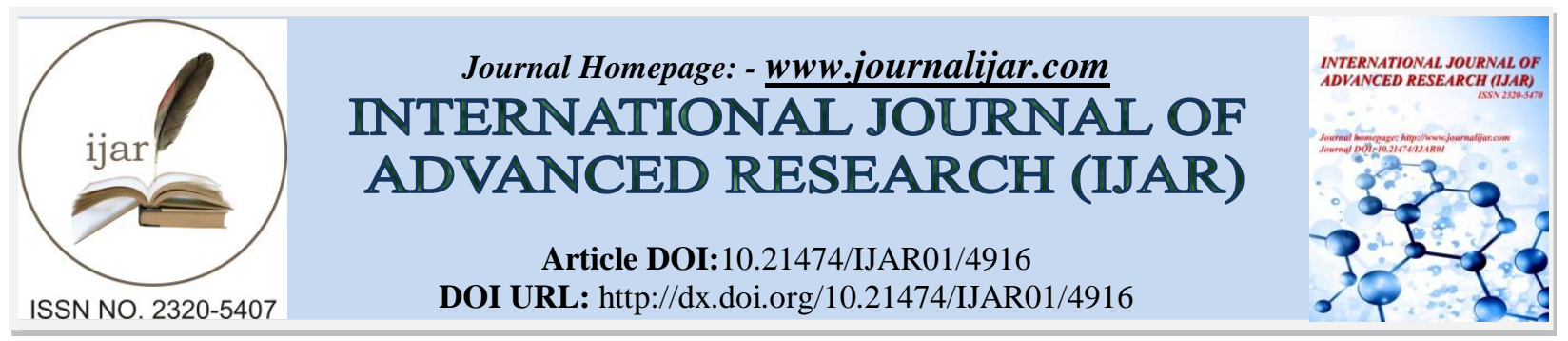

RESEARCH ARTICLE

\title{
AN INTERVENTION STUDY FOR RURAL ADOLESCENTS LIVING WITH ALCOHOLIC PARENTS IN SHILLONG, MEGHALAYA.
}

\section{Lindsay Murray M Sangma ${ }^{1}$ and Prof. Dr. Nirupama Prakash ${ }^{2}$.}

1. Ph.D. Research Scholar, Amity Institute of Social Sciences, Amity University, Noida, Uttar Pradesh, INDIA.

2. Director \& Head, Amity Institute of Social Sciences, Amity University, Noida, Uttar Pradesh, INDIA.

\section{Manuscript Info}

(..........................

Manuscript History

Received: 22 May 2017

Final Accepted: 24 June 2017

Published: July 2017

Key words:-

Adolescents, Rural, Intervention,

Alcoholic Parents.

\section{Abstract}

Addiction is a family problem and is a major source of stress for family members. Children are more at risk of child abuse, neglect, and behavioral problems. Children of alcoholics develop poor self-image, face disturbance in their studies resulting in low marks, become school dropouts, and are more likely to become alcoholics themselves. Life skill intervention can serve as a remedy for the problems as it will help the adolescents to lead a better life and handle the situation in a positive way. Present Study was an attempt to provide intervention programme in the form of Life Skills for rural adolescents living with alcoholic parents in Shillong, Meghalaya, India. The Objectives of the study were, to provide intervention programme for the rural adolescents who are living with alcoholic parents, to study the impact of life skills programme among rural adolescents before and after the intervention. The instruments used for measurement were demographic profile, Children of Alcoholics Screening Test (CAST), (Pilat \& Jones, 1985), Life Skills Assessment Scale (LSAS), (Nair, Subasree \& Ranjan, 2010). The hypothesis is there will be no significant differences among rural adolescents on the basis of life skill intervention. The researcher has selected a descriptive research design in phase 1 and in phase 2 pre experimental research design was used and Purposive sampling was applied. The result of the present study revealed that the intervention was very effective among the adolescents in enhancing their level of awareness and positive improvement seen in life skills such as self-awareness skills, effective communication and critical thinking skills.

Copy Right, IJAR, 2017,. All rights reserved.

\section{Introduction:-}

Adolescence is a phase separate from both early childhood and adulthood. It is a transitional period that requires special attention and protection. Physically children go through number of transitions while they mature. The brain undergoes quite substantial developments in early adolescence, which affects emotional, physical and mental abilities. Adolescence is a crucial period and most of the adolescence cannot bear the tremendous pressure (from parents, teachers, communities, peer groups,) and responsibilities that imposed upon them. As adolescent girls and boys grow, they take on additional responsibilities, experiment with new ways of doing new things and push for independence. It is a period in which values and skills are developed that has great impact on well-being. Meghalaya 
being a tribal state follows different cultural rituals, customs, and traditions. Meghalaya's indigenous tribe Garo, Khasi, Jaintia follows matrilineal society. Each tribe has its own beliefs and customs and follows different rituals and ceremonies (About Meghalaya, 2017). In most rural areas of Shillong, Meghalaya, India, due to its low economic background and low literacy rate, most parents does not encourage the adolescence to opt for better education facilities. Due to lack of parent's guidance, the rural adolescents tend to drop out from schools at an early age. It is seen that due to low economic background, some parents forced their children to go for labor work or force them to help them in farming and cultivation or other work prospectus that can help them earn daily means of livelihood, when they reach or attain the age of 10 years or above. These are one of the many causes and factors that most children from rural areas are school drop outs at early age. Moreover, the educational facilities in rural areas are limited and the children once they passed out their primary school, they have to go far or out of their villages to avail the facility. This is also the one of the main reason contributing to an adolescence school drop outs. Meghalaya have the highest alcoholic problems due to illegal liquor vendors, out of hundred people seventy percent people of Meghalaya consume alcohol. Women are found more vulnerable of becoming alcoholic or consuming alcohol as compared to men because of prevailing drinking habit culture in the society (Lim, 2017). Children's development and lives leads to negative impact and environment where across studies have shown that children of alcoholic are more prone to bullying in school, poor attendance, behavioral problem, unsupported by parents in academic achievements, unable to concentrate and difficulty in understanding, adjustment problems, distress, stress relating to parents fight or argument impacting their daily situation, broken relationship with alcoholic parent, poor communication with parents, peer pressure and poor relationship with friends, neighborhood and in schools. The family members especially from poor families are the one who suffers the most due to alcohol dependence of the partner or parents. The wife and children are forced to work in low paid jobs to support the family, children are drop out of the schools and suffer from many health problems.

\section{Objectives:-}

1. To provide intervention programme for the rural adolescents who are living with alcoholic parents

2. To study the impact of life skills programme among rural adolescents before and after the intervention

\section{Hypothesis:-}

There will be no significant differences among rural adolescents on the basis of life skill intervention.

\section{Methods:- \\ Participants:-}

Participants consisted of 180 adolescents, 71(39.4\%) male and 109(60.6\%) female participants who met the inclusion criteria for the study. The sample for the study was collected from adolescents who are studying in class $6^{\text {th }}$ till class $10^{\text {th }}$ from rural places of Shillong, India, who fall under the age group of 10 to 19 years. The Purposive sampling design was selected and life skills intervention programme was conducted using structured and standardized questionnaire, in which each session was activity based and participatory in nature, both boys and girls who attended the programme and only an experiment group was included which was given intervention programme. Tools or instruments used for data collections were demographic data profile, Children of Alcoholics Screening Test (CAST) (Pilat \& Jones, 1985), Life Skills Assessment Scale (LSAS), (Nair, Ubasree, \& Ranjan, 2010).

\section{Procedure:-}

The data collection started after visiting four different schools from the rural areas of Shillong, and researcher also visited de-addiction centers to take the referral students for the programme. The researcher collected data from the participants only after their willingness and informed consent both from parents along with school head permissions. When the permission was granted the researcher met each participant individually, explained about the research and gave them the copies of questionnaires. Researcher began with a brief introduction to the whole study prior to the signing of the informed consent form. Descriptive research design was selected in phase (1) as the design is helpful to identify the demographic characteristics of the participants and in phase (2) pre-experimental research design was used. The only single group was included, that is experimental group whereas the control group was excluded. The Single group was pretested and then exposed to the intervention programme and later again the experimental group was post-tested. The Head of the Department was requested to return the Questionnaire duly filled in by the students for both pre and post-test. 


\section{Statistical Analysis:-}

The collected data were coded, classified and analyzed using statistical package for social sciences (SPSS) 23 version. The obtained data were analyzed using descriptive statistics like frequency and percentage, mean and standard deviation, t-test.

\section{Results:-}

Table No 1:-Title: To study the impact of life skills programme among rural adolescents before and after the intervention.

\begin{tabular}{|c|c|c|c|c|}
\hline Variables & Mean & $\mathrm{N}$ & Std. Deviation & Std. Error Mean \\
\hline Self-Awareness Pre & 34.3056 & 180 & 6.23837 & .46498 \\
\hline Self-Awareness Post & 35.8833 & 180 & 6.81296 & .50781 \\
\hline Empathy Pre & 33.5833 & 180 & 5.68530 & .42376 \\
\hline Empathy Post & 33.8556 & 180 & 5.20541 & .38799 \\
\hline Effective Communication Pre & 26.1444 & 180 & 4.77203 & .35569 \\
\hline Effective Communication Post & 25.0944 & 180 & 3.98278 & .29686 \\
\hline Interpersonal Relationship Pre & 33.5444 & 180 & 5.27387 & .39309 \\
\hline Interpersonal Relationship Post & 33.3611 & 180 & 4.97678 & .37095 \\
\hline Creative Thinking Pre & 24.9333 & 180 & 5.03685 & .37542 \\
\hline Creative Thinking Post & 25.3667 & 180 & 4.92616 & .36717 \\
\hline Critical Thinking Pre & 33.7167 & 180 & 5.87132 & .43762 \\
\hline Critical Thinking Post & 35.2500 & 180 & 5.45154 & .40633 \\
\hline Decision Making Pre & 32.4444 & 180 & 5.69153 & .42422 \\
\hline Decision Making Post & 32.7500 & 180 & 4.74003 & .35330 \\
\hline Problem Solving Pre & 29.4556 & 180 & 6.01053 & .44800 \\
\hline Problem Solving Post & 30.1056 & 180 & 6.02277 & .44891 \\
\hline Coping with Emotions Pre & 29.5833 & 180 & 6.13705 & .45743 \\
\hline Coping with Emotions Post & 29.3444 & 180 & 5.30660 & .39553 \\
\hline Coping with Stress Pre & 19.4500 & 180 & 5.85607 & .43649 \\
\hline Coping with Stress Post & 19.0444 & 180 & 5.07026 & .37791 \\
\hline Total LSAS Pre & 297.1611 & 180 & 36.30122 & 2.70573 \\
\hline Total LSAS Post & 300.0556 & 180 & 26.07568 & 1.94357 \\
\hline
\end{tabular}

The table 1 shows the impact of life skills programme among rural adolescents before and after the intervention. It is clearly evident that there is significant improvement in both pre and post condition showing an overall significant influence of life skills on their total scores of Life Skills Assessment Programme. The intervention can, thus, be said to have a highly significant effect on adolescents.

Table No 2:-Title: There will be no significant differences among rural adolescents on the basis of life skill intervention.

\begin{tabular}{|c|c|c|c|c|c|c|c|c|}
\hline \multirow{3}{*}{ Variables } & \multicolumn{5}{|c|}{ Paired Differences } & \multirow[t]{3}{*}{$\mathrm{t}$} & \multirow[t]{3}{*}{$\mathrm{df}$} & \multirow{3}{*}{$\begin{array}{l}\text { Sig. } \\
(2- \\
\text { tailed) }\end{array}$} \\
\hline & \multirow[t]{2}{*}{ Mean } & \multirow[t]{2}{*}{$\begin{array}{c}\text { Std. } \\
\text { Deviation }\end{array}$} & \multirow[t]{2}{*}{$\begin{array}{l}\text { Std. } \\
\text { Error } \\
\text { Mean }\end{array}$} & \multicolumn{2}{|c|}{$\begin{array}{l}\text { 95\% Confidence } \\
\text { Interval of the } \\
\text { Difference }\end{array}$} & & & \\
\hline & & & & Lower & Upper & & & \\
\hline $\begin{array}{l}\text { Self -Awareness Pre } \\
\text { Self-Awareness Post }\end{array}$ & -1.57778 & 9.45732 & .70491 & $\begin{array}{r}- \\
2.96877\end{array}$ & $\begin{array}{r}- \\
.18678\end{array}$ & $\begin{array}{l}- \\
2.238\end{array}$ & 179 & .026 \\
\hline $\begin{array}{l}\text { Empathy Pre } \\
\text { Empathy Post }\end{array}$ & -.27222 & 8.39382 & .62564 & 1.50680 & .96235 & -.435 & 179 & .664 \\
\hline $\begin{array}{l}\text { Effective } \\
\text { Communication Pre } \\
\text { Effective } \\
\text { Communication Post }\end{array}$ & 1.05000 & 6.59632 & .49166 & .07980 & 2.02020 & 2.136 & 179 & .034 \\
\hline $\begin{array}{l}\text { Interpersonal } \\
\text { Relationship Pre } \\
\text { Interpersonal Post }\end{array}$ & .18333 & 7.44250 & .55473 & -.91132 & 1.27799 & .330 & 179 & .741 \\
\hline
\end{tabular}




\begin{tabular}{|c|c|c|c|c|c|c|c|c|}
\hline $\begin{array}{l}\text { Creative Thinking Pre } \\
\text { Creative Thinking } \\
\text { Post }\end{array}$ & -.43333 & 7.43546 & .55421 & 1.52695 & .66028 & -.782 & 179 & .435 \\
\hline $\begin{array}{l}\text { Critical Thinking Pre } \\
\text { Critical Thinking } \\
\text { Post }\end{array}$ & -1.53333 & 8.35417 & .62268 & $2.76208^{-}$ & -.30459 & $\overline{-}-462$ & 179 & .015 \\
\hline $\begin{array}{l}\text { Decision Making Pre } \\
\text { Decision Making Post }\end{array}$ & -.30556 & 7.75325 & .57789 & $\begin{array}{r}- \\
1.44591 \\
\end{array}$ & .83480 & -.529 & 179 & .598 \\
\hline $\begin{array}{l}\text { Problem Solving Pre } \\
\text { Problem Solving Post }\end{array}$ & -.65000 & 8.79720 & .65570 & $1.94391^{-}$ & .64391 & -.991 & 179 & .323 \\
\hline $\begin{array}{l}\text { Coping with } \\
\text { Emotions Pre Coping } \\
\text { with Emotions Post }\end{array}$ & .23889 & 7.99397 & .59584 & -.93688 & 1.41465 & .401 & 179 & .689 \\
\hline $\begin{array}{l}\text { Coping with Stress } \\
\text { Pre } \\
\text { Coping with Stress } \\
\text { Post }\end{array}$ & .40556 & 7.18526 & .53556 & -.65126 & 1.46237 & .757 & 179 & .450 \\
\hline $\begin{array}{l}\text { Total LSAS Pre } \\
\text { Total LSAS Post }\end{array}$ & -2.89444 & 48.79366 & 3.63686 & $\begin{array}{l}- \\
10.07109\end{array}$ & 4.28220 & -.796 & 179 & .427 \\
\hline
\end{tabular}

The comparative scores among rural adolescent's subjects show that there is significant difference among rural adolescents on life skill in pre and post condition in self-awareness, effective communication and critical thinking after intervention was given.

\section{Discussion:-}

The findings shows that out of 180 participants, 94(52.2\%) participants belongs to the age group of 14-15 years, $109(60.5 \%)$ majority of the participants are female, 73(40.5\%) participants are studying in class $9,152(84.4 \%)$ participants belongs to nuclear family, 120(66.7\%) participants falls in Scheduled tribe, 120(66.7\%) participants belongs to Christian. In the impact of life skills programme among rural adolescents before and after the intervention, it clearly shows that there is significant improvement in both pre and post condition showing an overall significant influence of life skills on their total scores of Life Skills Assessment Programme. The intervention can, thus, be said to have a highly significant effect on adolescents. The comparative scores among rural adolescent's subjects show that there is significant difference among rural adolescents on life skill in pre and post condition in self-awareness, effective communication and critical thinking after intervention was given. This study is in support with (Gopalakrishna, 2014\& Anuradha, 2014), where in their studies also showed that the intervention program was effective in enhancing the self-concept and that the adolescents scored reasonably a good score on life skills such as decision making, effective communication, self-awareness, problems solving, critical thinking, and inter-personal relationship skills which showed that adolescents are well equipped with life skills so also in my study students were more equipped with self-awareness skills, effective communication and critical thinking.

\section{Conclusion:-}

This study presented the obtained results to meet the objectives of the research. The results of group differences using t-test suggest that the intervention was very effective among the adolescents in enhancing their level of awareness and other life skills. This indicates that intervention was effective in making subjects more aware of their major skills especially in self-awareness skills, effective communication and critical thinking skills. Finally, the evaluation study confirmed that subjects found both the program and the facilitator effective.

\section{References:-}

1. About Meghalaya. (2017). Retrieved June Tuesday, 2017, from Government of Meghalaya: http://meghalaya.gov.in/megportal/stateprofile

2. Anuradha, K. (2014, February). Assessment of Life Skills Among Adolescents. International Journal of Scientific Research, 111(11).

3. Gopalakrishna, R. (2014, April). Enhancement of Self Concept Using Life Skills Approach. Research Direction Journal, 1(10). 
4. Lim, T. (2017). Alcoholism is responsible for misfortunes in Meghalaya, does government cares. Retrieved June Tuesday, 2017, from Meghalaya Times: http://meghalayatimes.info/index.php/editorial/19471-alcoholismis-responsible-for-misfortunes-in-meghalaya-does-government-cares

5. Nair, A. R., Subasree, R., \& Ranjan, S. (2010). Manual for Life Skills Assessment Scale. Chennai: Schools of Life Skills Education and Social Harmony Rajiv Gandhi National Institute of Youth Deveelopment.

6. Pilat, J. M., \& Jones, J. W. (1985). Identification of Children of Alcoholics: Two Empirical Studies. Alcohol Health \& Research World, 9(2), 27-33. 